\title{
ENTRE O SER E O NÃO-SER: o processo de construção da idéia de ator (profissional) à luz de Georg Simmel
}

Rosi Marques Machado*

Resumo: Neste artigo, analiso o processo de construção da idéia de ator profissional, desde sua origem até a que predomina no discurso dos que se dedicam a essa atividade nos dias de hoje. Com base na bibliografia especializada sobre o ator e à luz das reflexões de Georg Simmel, apresentarei quatro tipos ideais de ator que elaborei para evidenciar as mudanças ocorridas na noção de ator e as suas correspondentes formas-padrão de representação em acompanhamento às formas que a valorização do indivíduo assumiu ao longo do período moderno. Os quatro tipos ideais de ator são: o "ator-declamador-ilustrador”, o "ator-racional-realizador”, o "grande ator” e o "ator-psicológico-criador”. É neste último tipo que identifico a noção de ator de Stanislavski - que, em larga medida, marca, ainda, o discurso atual dos atores profissionais - e a associo à própria concepção simmeliana de indivíduo moderno, que se caracterizaria por sua ambigüidade.

Palavras-chave: ator profissional; indivíduo; modernidade; Georg Simmel.

\section{Introdução}

É muito comum, na literatura especializada na história do teatro ou do ator, certa tendência a remeter a idéia de ator para um

* Doutora em Ciências Sociais pelo Programa de Pós-Graduação em Ciências Sociais da Universidade do Estado do Rio de Janeiro (PPCIS/UERJ). Professora do Departamento de Ciências Sociais da Pontifícia Universidade Católica do Rio de Janeiro (PUC-Rio) e do Instituto de Humanidades da Universidade Cândido Mendes (Ucam).

Artigo recebido em 5 ago. 2008 e aprovado em 30 set. 2008. 
passado bastante remoto, chegando até mesmo a se falar na existência de "formas primitivas [de teatro] desde os primórdios do homem" (Berthold, 2001, p. 1). Assim concebidos, teatro e ator teriam suas origens no ritual e nas figuras do xamã ou feiticeiro, o que, de certo modo, confere um caráter mágico ao teatro e à atividade do ator. Um exemplo de como essa concepção ecoa atualmente no discurso dos atores profissionais ${ }^{1}$ é a utilização, por vezes, de determinada analogia para tentar definir o ato de representar: "é como se tivesse baixado um santo", denotando uma associação com o ato ritualístico de incorporar "entidades".

Apesar de essa relação teatro-ator e ritual-xamã ser possível e bastante sedutora à medida que permite criar, como diria Elias (1997), uma "longa e respeitável ascendência" para a idéia de teatro e ator, a equivalência direta entre os dois pares requer alguns cuidados. Afinal, estabelecer um continuum entre eles é o mesmo que assumir uma atitude de olhar o passado com os olhos do presente, o que implica renunciar à história, uma vez que são desconsiderados os significados específicos atribuídos às coisas nos seus devidos contextos.

Pensando nesses significados e contextos específicos, é possível perceber outra dimensão da idéia de ator que molda o discurso dos atores profissionais nos dias de hoje: aquela em que se enfatiza a necessidade da separação entre ator e personagem. Afirmada como uma especificidade que constitui a própria profissão, tal separação aponta para a definição do termo ator como encontrada nos dicionários: "homem que sabe fingir". Isso significa pensá-lo como quem sabe se fazer passar pelo que não é, quem sabe exprimir determinados sentimentos e pensamentos que, na verdade, não sente nem pensa. Isto é, o ator é aquele que sabe fazer parecer real aos olhos de quem assiste a ele o que é "falso" ou inexiste, uma vez que é criado na imaginação. Portanto, quem tem por atividade profissional "ser outro”, "passar-se por outro". 
Tendo-se em vista essa definição, chama atenção a sua relação com a própria noção de indivíduo que se inaugura na modernidade. Como afirma Duvignaud (1972, p. 42), a idéia de ator, de um homem que cria "com o corpo e a palavra um universo de paixões e emoções que define uma imagem de pessoa irredutível à ordem estabelecida" vai se formando à medida que as sociedades arcaicas ou tradicionais dão lugar às sociedades históricas. $\mathrm{O}$ processo de construção da idéia de ator é correlato ao deslocamento da própria concepção do homem, assim como do mundo. É a partir de um conjunto de mudanças - econômicas, políticas, sociais, religiosas e culturais - que o homem começa a se perceber como agente, que, a partir de seus próprios recursos, constrói o mundo a sua volta, o seu papel e a sua posição nele e, ao fazê-lo, constrói a si próprio, a sua individualidade. Acompanhando-se esse processo, pode-se chegar à idéia de ator tal como se apresenta como predominante no discurso dos que se dedicam a essa atividade profissional nos dias de hoje: um ser separado dos demais (incluindo aí os personagens) e dotado de uma capacidade de observar e identificar as emoções de outro e, ao mesmo tempo, de controlar as suas próprias emoções a tal ponto que pode “emprestar” algumas delas a um “outro”, o personagem.

Este artigo tem por objetivo provocar uma reflexão sobre a construção da idéia de ator observada na bibliografia especializada e sobre sua relação com a valorização da individualidade na época moderna, mediante a apresentação de quatro tipos ideais de ator que elaborei à maneira de Weber (1974) e à luz da reflexão de Simmel, especialmente, em seus ensaios dedicados à atividade do ator. Os quatro tipos ideais de ator são: "ator-declamador-ilustrador", "atorracional-realizador", "grande ator" e "ator-psicológico-criador". Os três primeiros foram concebidos em correspondência aos tipos de individualismo assinalados por Simmel, respectivamente: o da distinção, que marcaria o período da Renascença, o quantitativo do século XVIII, e o qualitativo do século XIX. Para isso, tomei como referência a bibliografia sobre o ator na França - centro cultural 
mundial nesses períodos. Quanto ao quarto tipo, eu o concebi em correspondência ao que Simmel denomina "ator artístico", no qual identifico a noção elaborada por Constantin Stanislavski que, com o seu método, marcará o universo do ator até os dias de hoje e que, a meu ver, se relaciona com a concepção simmeliana de indivíduo moderno caracterizada pela ambigüidade de ser, ao mesmo tempo, um todo em si mesmo e um elemento no todo.

Com efeito, a correspondência que faço entre os tipos de atores e as formas de individualismo tratadas por Simmel aponta para uma periodização mais ou menos precisa, o que poderia gerar certa compreensão equivocada, como a de que o ator-declamadorilustrador se encerrou no século XVII ou, ainda, a de que o atorracional-realizador se esgotou no século XVIII, assim como o grande ator no século XIX. Entretanto, é bom assinalar o caráter típico ideal que atribuo a eles. Em termos weberianos, esses tipos ideais de ator são instrumentos de análise, ou melhor, constructos intelectuais dos quais me sirvo para compreender a realidade social ${ }^{2}$, para desenvolver uma interpretação acerca dos fenômenos assinalados. Assim sendo, na observação da dinâmica do processo histórico, podemos encontrar esses tipos ideais de atores “contracenando” entre si no decorrer dos séculos e, por vezes, o entrelaçamento desses tipos em um mesmo ator ao longo de sua trajetória profissional. Porém, somente para efeito de exposição de uma análise que se encontra em processo, isto é, para acentuar certas especificidades na compreensão do significado que a atividade do ator foi assumindo ao longo do período moderno, neste artigo, eu apresento tais tipos ideais de ator como atrelados a determinado século.

\section{Individualismo da “distinção” e o surgimento de uma idéia de ator: o declamador-ilustrador}

Segundo Simmel (1998), a forma específica que a valorização do indivíduo assume nos séculos XVI e XVII se associa à ênfase dada 
pela Renascença italiana a determinados princípios que envolvem a emancipação do indivíduo com relação às "formas comunitárias medievais” ou tradicionais que até então o controlavam, impedindo-o de se ver como inseparável do grupo ${ }^{3}$. A ênfase renascentista em tal emancipação acabou por propagar "a vontade de poder, fama, prestígio e distinção em um grau desconhecido até então” (Simmel, 1998, p. 109). Como os seus próprios exemplos apontam, Simmel identifica esse tipo de individualismo entre os nobres, assinalando que a motivação básica, aí, é a busca de distinção, ou melhor, o “desejo individual de aparecer”.

Como esse primeiro tipo de individualismo se mostra central para pensar o surgimento da idéia de ator profissional, e como ele é pouco enfatizado na reflexão simmeliana, recorro, aqui, à análise de Elias (2001) sobre a sociedade de corte. Buscando esclarecer teoricamente as propriedades estruturais - tais como urbanização, monetarização e comercialização - do estágio de desenvolvimento atingido com o funcionamento efetivo dos controles centrais na sociedade de corte, Elias analisa três aspectos de um "impulso de distanciamento mais abrangente”. O primeiro diz respeito a um distanciamento em relação à natureza, a constituição de uma vida urbana de corte cada vez mais diferenciada da vida rural, impulsionando as pessoas a vivenciarem a natureza como "mundo dos 'objetos', como o que deve ser explorado" (Elias, 2001, p. 243) e, por conseguinte, controlado. O segundo aspecto trata de um distanciamento entre os indivíduos, que se relaciona à "couraça das autocoerções" desenvolvida pelos homens das elites no convívio na corte, levando-os a conter “os impulsos espontâneos” e, ao mesmo tempo, a observar e calcular o movimento dos seus pares e as suas chances de prestígio - o que aponta, mais especificamente, para uma racionalidade de corte ${ }^{4}$ ou ainda para o "desejo individual de aparecer” assinalado por Simmel. E o terceiro aspecto refere-se a um autodistanciamento, uma capacidade que "está intimamente ligada, do ponto de vista estrutural, ao desenvolvimento de uma couraça 
mais forte para proteger o indivíduo, na forma de um autocontrole, às vezes mais, às vezes menos automático" (Elias, 2001, p. 245246).

À medida que uma vida urbana de corte se constitui e à medida que, conforme assinala Duvignaud (1972), o ator surge acompanhando o movimento dos nobres, é possível pensar que esse ator também tenha começado a vivenciar a "natureza” cada vez mais como algo contraposto a ele, como "mundo dos objetos”. A tradução disso na idéia de ator que se esboça nessas sociedades seria o estabelecimento de uma diferenciação entre a pessoa do ator e o personagem-objeto: personagem a tal ponto objetivado, que adquire a forma de texto, propriamente, o que remete para o desenvolvimento de uma dramaturgia que caracteriza o teatro neoclássico, em contraste com o teatro medieval e a commedia dell'arte. Isso, por sua vez, é um bom indicador de que essa idéia de ator nasce entrelaçada com o próprio desenvolvimento da figura do autor e de uma forma de representação específica: a de ator-declamador.

Tal forma de representação vem anunciada no texto, ao qual o ator deve submeter-se, e equivale ao tipo de controle privilegiado em uma sociedade de corte. Portanto, diz respeito a uma "couraça de autocoerções", que se traduz por um refinamento do comportamento e por um cuidado com as palavras. Nesse sentido, pode-se dizer, inicialmente, que se tornar ator-declamador acaba por configurar um tipo de distinção que reproduz, de certa maneira, a separação mais ampla da sociedade de corte. Assim como esta se dividiria, em linhas gerais, entre “quem é nobre” e “quem não é”, haveria, também, uma espécie de distinção entre “quem é ator” e “quem não é ator”. Com efeito, a separação entre nobres e não-nobres obedece, sobretudo, ao critério do nascimento - os laços consangüíneos, o "sangue azul" -, enquanto a distinção entre ator e não-ator se apoiaria, antes, na capacidade do indivíduo de desenvolver ou não uma "couraça de autocoerções". 
Assim sendo, o não-ator é aquele que não possui tal capacidade à medida que se confunde com a personagem e dá vazão a "impulsos espontâneos", ou seja, utiliza-se de formas de expressão "exageradas" para desempenhar um "papel" - até mesmo social, como parece ser o caso dos bobos da corte. O ator, por sua vez, é, antes de tudo, o indivíduo que, ao desenvolver uma "couraça de autocoerções", distancia-se do personagem, observa e calcula o movimento desse personagem com os demais. Sem dúvida, isso requer também uma capacidade de autodistanciamento, um autocontrole, que traduz, por sua vez, o controle sobre um saber específico.

O saber do ator assim caracterizado compreende: extrair do texto os elementos dados pelo dramaturgo para caracterizar o seu personagem - denotando a "autoridade" do texto; controlar tais elementos e, assim, expressar o personagem-objeto por meio de uma forma de representação que traduz o comedimento e polidez exigidos pelos nobres, e que se caracteriza por controlar os gestos e a voz. Saber conter os gestos e valorizar a palavra é atender ao gosto cortesão expresso no texto. Saber controlar a voz, modulando-a de acordo com os versos decassílabos, é declamar o texto. Portanto, aqui, ator é sinônimo de ator-declamador, cujas "chances de prestígio" se associam a agradar o gosto cortesão expresso no texto. É dessa maneira que ele realizaria o seu "desejo individual de aparecer”. Aparecer aos olhos da nobreza, já que é esta que lhe confere legitimidade.

Dentro dessa sociedade regida por uma racionalidade de corte, ser reconhecido como “artista sério”, um “artista-artesão”, ou seja, ser serviçal de um nobre é sinal de prestígio, logo, uma forma de atender ao "anseio de se distinguir da massa dos homens" (Elias, 2001, p. 113). Além disso, sob a "pressão de uma competição contínua" pelo poder-prestígio, os atores-declamadores buscam destacar-se entre si. Quanto mais capaz for de tornar o texto compreensível e inteligível, através de sua dicção e imagem, mais capaz será esse 
ator de elucidar, de materializar o texto no palco, servindo-lhe como uma ilustração. Nesse sentido, esse ator pode, também, tornar-se ilustre, reconhecido pelas principais cortes, quem sabe, a corte do rei. Por isso, pode-se chamá-lo de ator-declamador-ilustrador.

Com efeito, à medida que a rede de interdependências humanas vai se tornando mais e mais complexa, o individualismo de “distinção” vai se esgotando, pois, como ressalta Simmel, "reside na própria natureza das coisas [...] que esse desejo (individual de aparecer) e essa satisfação não possam ser um traço permanente do homem ou da sociedade, tendo de desaparecer da mesma forma que um estado extático" (Simmel, 1998, p. 109-110). Assim, se, nas sociedades de corte, se desenvolve uma determinada idéia de ator fundamentada em uma concepção de indivíduo cuja motivação básica é o "desejo individual de aparecer", que se expressa na formapadrão de representação do ator declamador-ilustrador, à medida que essas sociedades começam a se desestruturar, ou, melhor dizendo, à medida que a rede de interdependências vai se tornando mais complexa com a ascensão da burguesia como força econômica e política, a tendência de valorização do indivíduo na modernidade assume outra forma de individualismo que irá caracterizar o século XVIII, qual seja, a do "individualismo quantitativo", e, com ele, outra idéia de ator vai se esboçando.

\section{Individualismo “quantitativo" e o ator-racional- realizador}

De acordo com Simmel (1998, p. 109-110), a forma que a valorização do indivíduo assume no século XVIII tem como motivação a liberdade individual, fundamentada na perspectiva de que os homens são naturalmente iguais. Nesse sentido, à medida que o Iluminismo propaga a idéia de que a razão é algo que cada indivíduo traz consigo, portanto, trata-se de algo inato, ele nega a tradição: tanto 
iguala todos os homens como os liberta das "correntes opressivas" da sociedade - as "amarras sociais" representadas pelas instituições do Antigo Regime. Logo, aqui temos a afirmação do indivíduo como separado, isolado do grupo. Porém, resta a questão: então, como é possível a existência da sociedade? A resposta é encontrada na noção de fraternidade: a "renúncia eticamente voluntária”, que integraria esses indivíduos "livres-isolados" e tornaria possível a vida social, compondo um "ambiente social" harmônico.

Com efeito, nessa resposta se encontra a perspectiva de sociedade própria ao liberalismo racional inglês e francês, ou seja, a que corresponde à noção da livre concorrência. Trata-se de uma sociedade vista como composta por indivíduos que têm as mesmas capacidades - razão - e que têm liberdade para dar vazão à sua própria "ambição" e, assim agindo, isto é, competindo com os demais, cada um dá o "melhor” de si e contribui para o equilíbrio do todo, em outras palavras, para a "riqueza das nações".

Desse modo, Simmel considera esse tipo de individualismo como derivado do desenvolvimento da economia monetária, daí a sua denominação, quantitativo, pois é na medida em que a troca supõe algo de comum, o dinheiro, que este se transforma no suporte das relações entre os homens, tornando-as impessoais. Isto é, ao afastar tudo que é pessoal, o dinheiro acaba nivelando os indivíduos, tornando-os indiferenciados, anônimos, iguais. Ao mesmo tempo, passa a ser o suporte da liberdade individual: seu caráter móvel permite a ampliação dos círculos sociais, vinculando o sujeito ao todo, não como pessoa por inteiro, mas, sobretudo, "pela doação e recepção de dinheiro". É nesse sentido que Simmel afirma que o dinheiro vem a ser "um novo fio condutor para os conteúdos de vida que podem ser associados" (Simmel, 1998, p. 25).

Até mesmo em correspondência às características do dinheiro é que se pode dizer que o indivíduo quantitativo se caracteriza por 
ser genérico, universal e abstrato. A meu ver, essa concepção de indivíduo fundamenta a idéia de ator racional contida no método proposto por Diderot (1993), método este elaborado a partir de observações feitas entre alguns atores reconhecidos pela sociedade de sua época, vale lembrar, uma sociedade monárquica centralizadora já em processo de desestruturação. Isso significa dizer que é a partir dos atores-declamadores que Diderot estabelece uma diferenciação. Por um lado, os atores que "interpretam com a alma" ou intuitivos, que "viveriam" as emoções do personagem e, com isso, apresentariam uma irregularidade em suas representações; atores que representam dentro das "amarras" do comportamento cortesão, comportamento não mais visto como comedido, mas, sim, afetado. Por outro lado, Diderot identifica os que considera bons atores: os de "cabeça fria". Estes são os que sabem controlar não só as características externas do personagem, como também as internas, as emoções do personagem e as suas próprias emoções.

É nesse sentido que Diderot redimensiona a relação entre ator e personagem, aprofundando a esfera do controle que o ator deve ter, atribuindo-lhe uma característica central: a razão. A essência racional do ator é que o torna capaz de decifrar a "verdade do personagem”, o modelo criado pelo dramaturgo - que, sendo um "iluminista", escreve para um "homem genérico, abstrato e universal”, isso que é o fundamento do drama burguês. Essa essência também se anuncia na capacidade do ator de observar, no "palco da comédia do mundo" - o mundo real, espécie de laboratório para o ator - as "características mais genéricas e mais marcantes" dos homens que se aproximam do modelo concebido pelo dramaturgo. Por fim, torna o ator capaz de "revelar" a verdade ou essência do personagem transpondo-as para o "mundo do palco", portanto, adequando-as às "leis cênicas". Tais leis se traduzem na perspectiva da "quarta parede” apontada por Diderot. $\mathrm{O}$ ator deve imaginar uma grande parede que o separa da platéia e representar "como se a cortina não estivesse aberta”. 
Assim, ele deve utilizar os gestos e a voz de maneira mais "natural” que condiga ao "mundo da realidade", porém deve dar-lhes uma amplitude que preserve o "exagero" requerido pelo "mundo do palco", possibilitando ao espectador sentado na última fileira do teatro assistir ao espetáculo.

Desse modo, o ator de "cabeça fria” sabe que não é o personagem que representa, ele não se ilude. Ele domina as suas próprias emoções. Nesse sentido, é livre, "um indivíduo em si mesmo”. O que o ator faz, diz Diderot, é promover a ilusão do espectador. Racionalizando a sua emoção no palco, o bom ator é capaz de destacar a singularidade do personagem e, assim, representa “o Tartufo”, e não "um tartufo” encontrado na realidade. Representando a essência do personagem, o bom ator é capaz de conduzir a emoção do espectador a tal ponto que este acaba por confundi-lo com o personagem. Aos olhos do espectador, também dotado de uma essência racional, o personagem é real, ou, melhor dizendo, o espectador identifica todos os tartufos do mundo naquele que está no palco. Concebido dessa forma, o ator seria um realizador do personagem, à medida que lhe confere uma concretude.

Essa idéia de ator parece estar em conformidade com um tipo de movimento teatral: o naturalismo, tratado por Simmel em seus ensaios sobre o ator. Ao que tudo indica, Simmel se refere ao chamado naturalismo teatral lançado por Zola no final do século XIX, porém, devido à influência de Diderot sobre Zola - claramente manifesta por este em seu texto "O naturalismo no teatro" -, utilizome da análise de Simmel sobre o movimento do século XIX para tratar do método desenvolvido por Diderot.

Segundo Simmel (1967, 1992, 1994), o naturalismo teatral parece se fundamentar em uma primeira impressão, e popular, que se tem da arte: a de que a sua matéria é fornecida pela realidade concreta; assim, caberia ao artista transportar essa realidade para 
a forma de obra de arte, para "algo além da vida”. Essa primeira impressão se inverte quando se trata da arte dramática. Como esta apela, mais do que qualquer outra arte, ao público imediato, e como a matéria do ator já é obra de arte, caberia a ele transportar esta para a realidade. Apoiado nessa compreensão, o naturalismo teatral concebe que é por meio do ator que a obra poética se faz real e, com isso, tem a pretensão de atar a arte dramática à esfera da realidade.

Dentro dessa pretensão, Simmel identifica uma concepção "sutil e tentadora" - na qual identifico a de Diderot - que compreende que o ator deve representar seu personagem, simplesmente, de acordo com a literatura. Aqui se parte da seguinte idéia: do personagem objetivado em um texto são "demandadas exigências rígidas às quais o ator deve submeter-se”. Assim, a maneira ideal de representar um personagem é determinada pelo personagem em si, pela intenção do escritor, pela questão "objetiva e fixa" contida no texto. Daí a idéia de que todo personagem teria "uma única representação dramática 'correta', da qual o ator empírico se aproximaria" (Simmel, 1967, p. 78).

Para esse autor, essa objetividade conferida ao trabalho do ator não significa um ideal dramático, mas, sim, literário, pois, à medida que o ator forma de modo conseqüente o personagem, ele materializa o que foi idealizado pelo escritor, ele é um mero realizador de seu personagem, uma "marionete do seu papel”. Essa "concepção literária" do ator traz consigo uma "tentação secreta”: a de dar uma aparência de realidade à obra literária. Assim, conclui Simmel, por mais bonita que seja a frase de que "o ator dá vida ao drama”, isso leva à negação da arte dramática como arte propriamente - ou seja, como algo “autêntico e incomparável”. Dividido entre os princípios da obra literária e os da realidade, ao ator caberia somente compor mecanicamente o seu personagem de acordo com tais princípios.

Segundo Simmel, essa "concepção literária" expressa uma falsa objetividade, pois, se, por um lado, o texto se encontra em um 
plano mental e unidimensional, em que o escritor ou dramaturgo traça o destino e a "alma" do personagem, por outro lado, o texto não pode dar conta, nem dar "premissas inequívocas” da entonação e velocidade da fala, dos gestos, da "atmosfera" visual da figura ou de sua vivacidade ("o calor da vida"). É o ator quem transfere esse plano unidimensional para o plano tridimensional da sensibilidade plena. Para Simmel, o ator não torna o drama - ou obra literária real, mas, sim, o torna sensível. É nessa transferência que o ator desempenha a sua tarefa artística, ou seja, ele cria.

Ao que tudo indica, o ator "cabeça fria" de Diderot expressa essa "falsa objetividade" à medida que, para ele, o bom ator "observa os fenômenos; o homem sensível serve-lhe de modelo e ele medita-o, por reflexão encontra o que é preciso acrescentar ou cortar para ficar melhor" (Diderot, 1993, p. 53). Observar os "fenômenos" e meditar sobre o modelo do "homem sensível”, o personagem literário, é perceber-se como "um indivíduo em si mesmo": um ser separado dos demais, mas que tem uma "essência racional” comum com eles, o que permite ao ator refletir sobre a coerência, a lógica intrínseca ao personagem que conduz a certa emoção. Emoção do personagem. O ator "acrescenta” ou “corta” essa emoção, ele calcula, separa as suas emoções reais e as domina a tal ponto que o resultado do seu trabalho, ou seja, o personagem pronto que se realiza diante do público não tem nada de seu. Considerando isso, eu o denomino de ator-racionalrealizador e o relaciono à forma de "individualismo quantitativo" que caracteriza o século XVIII e servirá de contraponto, junto ao ator-declamador-ilustrador, ao tipo de individualismo que se funda no século seguinte: o “qualitativo”.

\section{Individualismo “qualitativo" e o "grande ator"}

De acordo com Simmel (1998), o individualismo qualitativo só surge à medida que a igualdade e a liberdade se tornam valores 
universais, pois ele é uma reação ao individualismo do século XVIII e ao nivelamento causado pelo dinheiro. Trata-se de uma criação do “espírito germânico”, cujo fundamento artístico foi dado por Goethe, enquanto o metafísico, filosófico, foi dado por Schleiermacher. Complementando essa criação germânica, há "a base sentimental, da vivência” fornecida pelo romantismo, principal canal de propagação da concepção de Schleiermacher na qual cada indivíduo é “chamado a tornar realidade o próprio destino”, buscando em si o que lhe é único e distinto. Essa concepção, nas palavras de Simmel, “desaguou na consciência do século XIX” (Simmel, 1998, p. 115).

A motivação básica desse tipo de individualismo se encontra na busca da desigualdade, que se fundamenta em "uma lei interna": a necessidade de originalidade. Na busca do que lhe é único e distinto, o indivíduo deve "voltar-se para si”. Assim, a "alma romântica” busca o sentido da sua existência distanciando-se da "realidade exterior", do modo de viver burguês impregnado pelo dinheiro que transforma o indivíduo que "se apega a apenas um ponto" em uma “ostra racional” e valorizando os aspectos qualitativos do indivíduo, as suas particularidades e sentimentos. Por isso, como ressalta Waizbort (2000), o individualismo qualitativo é antiliberal e hostil à economia monetária, à impessoalidade produzida pelo dinheiro, que liga indivíduos que nem se conhecem. Mas, ao mesmo tempo, é derivado do desenvolvimento dessa mesma economia, que, no século XIX, atua sob dois princípios: a concorrência, fundamentada na teoria da liberdade e da igualdade do século XVIII, e a divisão do trabalho, cujo fundamento é a "personalidade diferenciada" (Simmel, 1998, p. 117).

A noção de originalidade que se contrapõe à impessoalidade, à racionalidade e ao universalismo vai marcar a teoria romântica teatral francesa. Conforme assinala Roubine (2003), as idéias de liberdade e igualdade propagadas pelos iluministas despertaram um “fascínio” nos homens do século XIX, mas este foi acompanhado 
de "frustração", pois acontecimentos como o Terror e as guerras napoleônicas logo lhes mostraram que tais ideais "não se cumpriram”. Vale lembrar que esses acontecimentos acompanham o movimento mais amplo da sociedade francesa em direção à nova ordem econômica, isto é, a afirmação de uma sociedade que está se industrializando e que promove um "nivelamento" dos indivíduos, tornando-os tão "pálidos” quanto o que serve de símbolo a essa sociedade, o dinheiro.

Dentro desse contexto, a doutrina romântica teatral francesa vai se aprimorando, especialmente, entre os anos 1820 e 1830. Não por acaso, nessas mesmas décadas, a França é marcada por um determinado debate que a concebe, de acordo com Ortiz (1991), como dividida em duas: a França do Norte, industrial, "rica e esclarecida", e a França do Sul, agrária, "obscura e atrasada". Tal discussão revela o conflito ideológico entre progressistas e conservadores franceses sobre a conveniência e as conseqüências da Revolução Industrial. Por um lado, os progressistas defendem a industrialização e a nova sociedade que se anuncia com ela. Por outro, os conservadores, que, inicialmente, viam essa industrialização e o “caos” que ela gerava como passíveis de serem evitados com o retorno de "um Antigo Regime idealizado”, mas, depois, aceitam esse "presente” e buscam se afirmar diante do novo quadro social, desenvolvendo uma série de questões em reação ao modo de viver e de pensar burguês. É essa reação conservadora que ilumina vários aspectos da reação romântica e do individualismo qualitativo.

Segundo Mannheim (1963), o pensamento conservador tergiversou sobre o postulado de igualdade dos liberais do século XVIII. Se estes pensaram a igualdade em termos do possível (abstrato), os conservadores do século XIX a traduziram em termos do real (concreto). Assim, converteram o postulado liberal em uma afirmação, fazendo parecer que os liberais reivindicavam que todos os homens fossem iguais de fato e em todos os aspectos. A seqüência 
lógica da forma concreta de perceber o mundo dos conservadores consiste em: uma vez que o real é apenas algo que existe, e uma vez que a realidade é marcada pela desigualdade em todos os seus aspectos, o que se conclui é que a "promessa” liberal, iluminista de uma "igualdade de fato" entre os homens não se cumpriu. Os românticos compartilham essa visão, daí a "frustração” assinalada por Roubine.

Em sua forma concreta de perceber o mundo a sua volta, de acordo com Mannheim, o pensamento conservador "aceita o presente", experimentando-o não como "o começo do futuro", mas "apenas como o último momento do passado" (Mannheim, 1963 , p. 125). Desse modo, ataca somente detalhes particulares do presente, procurando substituir "fatores individuais" por outros "melhores" ${ }^{6}$. É esse tratamento que os conservadores dispensam à noção de "liberdade individual" preconizada pelos liberais. Eles não a rejeitam como um todo, mas atacam um de seus aspectos: a idéia de igualdade que lhe serve de fundamento. Diante da própria necessidade de se afirmarem na esfera política, os conservadores criaram o seu próprio conceito de liberdade, recuperando um "modo anterior e quase extinto de pensar e experimentar as coisas", no qual "o simples hábito de viver" se dava de maneira "mais ou menos inconsciente”, ou seja, sem a "liberdade da mera racionalidade” do modo de viver burguês. Com isso, os conservadores desenvolvem a “idéia qualitativa” de liberdade, cujo fundamento está na noção de que os homens "são essencialmente desiguais tanto em suas atitudes e talentos como no núcleo mesmo de seu ser” (Mannheim, 1963, p. 119). Como chama atenção Mannheim, é essa idéia que Simmel denominou de "lei individual" de desenvolvimento.

Ainda segundo Mannheim, ao desenvolver a "idéia qualitativa” de liberdade, os conservadores acabaram tomando algo do liberalismo: a separação da vida em duas esferas. Por um lado, os conservadores subjetivaram o problema da liberdade, pois ela 
só pode estar no lado privado, na habilidade de cada um para se desenvolver de acordo com o princípio de sua própria personalidade. Por outro lado, submeteram as relações sociais externas ao princípio da ordem e disciplina, e, para impedir que as esferas da "liberdade subjetiva" e da "ordem externa" se chocassem, o pensamento conservador se apoiou no pressuposto de que há "uma espécie de 'harmonia preestabelecida', garantida já diretamente por Deus ou pelas forças naturais da sociedade e da nação” (Mannheim, 1963, p. 121). Esse conceito de nação é a forma conservadora de "fornecer um conjunto mais amplo", de conceber a significação das coisas, em reação ao modo liberal-revolucionário. Enquanto o progressista usa o futuro para interpretar as coisas, as pessoas e as instituições, o conservador atribui sentido a elas "arredondando-as" e encaixandoas em um contexto mais amplo por meio do que está "por trás" delas, seja o seu passado temporal, seja o seu germe evolutivo. Nessa perspectiva, parte-se do princípio de que "o passado vive no presente"; dessa maneira, a interpretação do mundo ao redor, do presente, só é possível quando se volta para o passado.

Nesses vários aspectos do pensamento conservador pode-se reconhecer a perspectiva dos dramaturgos românticos franceses e, dentro desta, o surgimento de um determinado tipo de ator no século XIX: o "grande ator".

Como ressalta Prado (1972, p. 51), o teatro romântico francês vai recuperar “a ingenuidade dos 'romanceros', o primitivismo genuíno da Idade Média” para libertar a dramaturgia “da tirania dos gregos e romanos”. Segundo ele, essa recuperação é “apenas para variar de passado, como se fosse viável esquecer o século dezenove”. A meu ver, seguindo a linha de Mannheim, parece haver algo mais na "variação" desse passado, pois se trata da escolha de um passado específico, aquele contra o qual se voltou a estética da "bela natureza" do neoclassicismo, a tradução teatral da racionalidade da sociedade de corte que instituiu as regras aristotélicas que continuavam a vigorar nos palcos franceses do século XIX. 
Nesse sentido, em seus dramas, os românticos voltam-se para um passado idealizado no qual se vivia de maneira mais ou menos inconsciente, distante da realidade exterior impregnada por uma racionalidade simbolizada pelas regras neoclássicas. Ao mesmo tempo, o artista romântico se refugia dentro de sua subjetividade, buscando sua "lei original artística”. Assim, quando Victor Hugo adverte que um romântico que imita outro romântico está se traindo, ele parece atentar para aquela "tarefa ética" que Simmel identifica em Schleiermacher, ou seja, para o caráter de dever com relação à originalidade.

Os dramaturgos românticos franceses vislumbram, em grande parte, tanto esse passado como essa originalidade no gênero teatral que surge nesse momento: o melodrama, que institui um mercado teatral. Como o sucesso ou não do espetáculo, nesse caso, depende diretamente dos públicos que compõem o cenário dos centros urbanos e industriais em formação, torna-se necessária a busca de uma comunicação “mais fácil” com esse público diverso e tão distinto daquele público "letrado” das peças neoclássicas. O resultado é uma valorização da ação e dos gestos - da pantomima - em detrimento da palavra, do texto. Por conseguinte, tal resultado significa, também, uma valorização dos “artesãos da cena”, os atores. Como destaca Prado, no melodrama, o teatro é concebido "como representação, e não como texto literário", possibilitando a "função criadora do ator", uma vez que é "da sua imaginação, da sua capacidade de infundir sangue e nervos às palavras, é que dependia o espetáculo" (Prado, 1972, p. 117). Desse modo, o texto era pretexto para o que ocorria em cena, afirmando uma forma de representação marcada por: sua tendência para o "exagero" - a "busca do patético a qualquer custo"; sua extroversão, "sem preocupações com a elegância ou com a pureza estilística"; e, ainda, "um realismo elementar, populista, visando sobretudo o pitoresco" (Prado, 1972, p. 116).

Um exemplo recorrente na bibliografia especializada sobre essa forma de representação é o do ator Frédéric Lemaître. Segundo 
Prado, Lemaître foi "o maior de todos esses atores populares, educados através dos aplausos e das vaias da platéia, formados em companhias baratas, à margem dos textos clássicos e da 'Comédie Française"', e que representava seus personagens dando ênfase à "parte da caracterização física, da mímica, do jogo de cena” (Prado, 1972, p. 113). Tal ênfase, como observa Duvignaud, fazia com que Lemaître reunisse as "impressões e observações transpostas", isto é, os elementos esparsos "em uma figura e, partindo desses dados, constrói[-uísse] um tipo" (Duvignaud, 1972, p. 140). Esse "tipo" corresponde à maneira que o ator encontra para impor-se perante os públicos dos quais depende diretamente, afirmando-se por "um personagem ao qual condiciona todas as peças que representa" (Duvignaud, 1972, p. 146).

O “tipo" que o ator do melodrama constrói e "vive” no palco se associa, conforme chama atenção Duvignaud, ao "engrandecimento sistemático de uma personalidade, de um caráter" que acaba por transformar o ator em "vedette". Ou seja, à medida que o ator "vive" no palco, nas palavras de Prado, "a emoção em estado nativo", e à medida que a sua "grande personalidade" se expressa no tipo que constrói, sobrepondo-se às características particulares que cada personagem possa conter, o ator acaba por se tornar um símbolo de liberdade, sobretudo, para os românticos.

Tais como os conservadores, os românticos partem do princípio de que "o passado vive no presente"; assim, interpretam o mundo ao seu redor, ou seja, atribuem sentido às coisas, às pessoas e às instituições do presente voltando-se para o passado, o que dá o tom saudoso à "alma romântica". É isso que Simmel parece dizer quando assinala que a "alma romântica” busca, de maneira incessante, um “equilíbrio” entre as "duas grandes forças da cultura moderna”, que podem ser traduzidas pelas duas esferas separadas da vida que os conservadores reproduziram do liberalismo: a da "liberdade subjetiva" e a da "ordem externa". Segundo Simmel 
(1998, p. 116), os românticos experimentaram essas "duas grandes forças" como "saudades": “a saudade da personalidade autosuficiente" e "a saudade da singularidade da própria vida com o outro". De qualquer forma, trata-se de "saudades” de algo que nunca se viveu, seja de algo que foi prometido e não cumprido ou de um passado idealizado.

Segundo Duvignaud (1972), a "paixão romântica e os símbolos que ela cria” foram testemunhas da "tentação" predominante nos homens desse período, que se resume no desejo de "um desenvolvimento completo do homem, sob todos os seus aspectos", mas que encontra limites nas "coações" e na "própria liberdade coletiva”. Assim, diante da perplexidade de se proclamarem livres e se sentirem incapazes para realizar essa liberdade, a figura do ator do melodrama se acentua aos olhos desses homens como um "indivíduo atípico”. Seguindo essa linha de argumentação, pode-se dizer que ele se torna um símbolo da paixão romântica pela liberdade: tanto de uma liberdade artística, expressa na espontaneidade e originalidade com que se apresenta nos palcos, quanto de uma liberdade individual, à medida que a exaltação da "grande personalidade" do ator transborda dos palcos para a sua própria vida particular, marcada por inúmeros episódios que denotam a mesma "explosão de emoções" vista no palco e que se tornam públicos, com a publicação de suas biografias e de notícias que envolvem o culto da vedette.

Nesse sentido, pode-se falar de uma ressignificação da idéia de ator no século XIX, na medida em que o "indivíduo atípico" entrevisto no ator do melodrama parece se configurar em uma espécie de versão romântica do "gênio criador" para a arte de representar: o "grande ator". Para perceber essa ressignificação, considero pertinente voltar à análise de Mannheim sobre a aproximação entre o romantismo e o pensamento conservador.

Como observa esse autor, em consonância com a perspectiva concreta dos conservadores sobre o mundo a sua volta, o 
romantismo também parte "sempre do caso particular que está à mão" e o seu interesse recai nos "detalhes concretos cambiantes", não na "estrutura do mundo em que vive". Assim, a meu ver, os dramaturgos românticos franceses atacaram um "detalhe concreto" no neoclassicismo: o "imperialismo da palavra”, com suas regras que se fundam na estética da bela natureza de Aristóteles e o racionalismo dos “requintes técnicos” presente na forma de representar dos seus atores. Em substituição, os românticos propõem outro e "melhor" detalhe, a "lei original artística”. Do mesmo modo, atacaram um "detalhe concreto" no melodrama: o texto. Com a pretensão de "melhorá-lo", buscaram dar-lhe: a) um conteúdo histórico, aproximando-se do sentido de conceito de nação do pensamento conservador; e b) uma dimensão literária ou filosófica, como Victor Hugo, ou uma dimensão dramatúrgica específica, como Alexandre Dumas. Isso significa que os românticos não atacaram a estrutura do plano literário como um todo, mas os que o tinham sob seu domínio naquele momento, os neoclássicos. Da mesma maneira, não atacaram a estrutura como um todo do melodrama, no caso, a "estrutura da narrativa", fundamentada na valorização da ação e das emoções, que também significa a valorização da "função criadora" do ator.

A meu ver, os românticos identificam, na forma de representar do ator do melodrama, algo que o distancia da racionalidade imposta pelo Conservatório, e a associam a uma forma de representar que se encontra no passado, no qual não havia um texto elaborado, mas, sim, um “esqueleto”, uma "estrutura da narrativa” que parece aludir à commedia dell'arte; ou ainda, associam-na à forma de representar dos atores ingleses que tanto admiravam, cuja característica fundamental é a originalidade, a explosão dos sentimentos.

Nesse contexto, os românticos reconhecem o ator do melodrama, conferindo-lhe prestígio e certa "densidade conceitual”: a sua liberdade é uma reação ao racionalismo do modo de viver que se instaurou no mundo moderno - entendendo-se, aí, tanto a 
racionalidade de corte quanto a burguesa; ele não se contém em uma forma, ele cria a sua própria forma. Isso o torna um "grande ator", um "gênio criador". Se, antes, o ator oriundo do melodrama era visto apenas como "extrovertido", com o reconhecimento dos românticos, ele torna-se "original”. Ele se legitima. Assim, Frédérick Lemaître, um ator formado nas peças melodramáticas sob o "calor” da sua relação com o público, acaba por se tornar um "grande ator”. De acordo com Prado (1972), Lemaître parece ser a expressão do que Victor Hugo defendeu no prefácio de sua peça Cromwell: a substituição do belo pelo característico, recusando, assim, “qualquer esforço de estilização" . Para Victor Hugo, Lemaître é "inigualável”, portanto, único, à medida que obedece a sua própria "lei individual e artística”.

Essa “originalidade” é que permite falar de uma “autonomização da arte do ator”, no sentido que Duvignaud atribui ao "grande ator": "esse ser sobrecarregado de um imenso prestígio afetivo não é em primeiro lugar o servidor de uma obra”. É o “grande ator" que imprime o seu estilo às "formas dramáticas"; pode-se dizer que ele se sobrepõe ao autor. E o estilo do "grande ator" está no fato de "viver" os "seus” personagens. Essa forma de representar vai se impor até mesmo na tragédia, revigorando-a, como diz Roubine ao tratar do estilo da atriz Rachel: "A influência da estética romântica lhe sugere um 'realismo' novo no palco trágico, no sentido de que pantomima e declamação são agora organicamente necessários a uma interpretação regida pela singularidade do personagem e da situação" (Roubine, 1987, p. 73-74).

Nesse sentido, essa forma de representar "vivendo" os personagens, no caso francês, parece se desenvolver seguindo um curso particular: nasce do melodrama, das exigências que os seus públicos fazem aos atores, que, por sua vez, dependem diretamente desses públicos; adquire prestígio por meio dos românticos, à medida que estes reconhecem nessa forma de representar a "originalidade" 
que falta aos atores neoclássicos; e acaba se confirmando como a forma-padrão de representação do século XIX, adentrando pela tragédia. Entretanto, essa forma de representar "vivendo" os personagens dá margem para pensar que esses atores "representam a si mesmos". É aqui que se pode identificar a falsa subjetividade desse tipo de ator de que nos fala Simmel.

Se a concepção de representação dramática do século XVIII - a de Diderot, com sua teoria da representação "correta" - expressa uma falsa objetividade do trabalho do ator, para Simmel, a concepção de que o ator deve atuar "só ele mesmo, isto é, de acordo com o que a natureza o criou” é uma "falsa subjetividade".

Trata-se de uma falsa subjetividade porque o personagem só seria a "roupagem" na qual, por acaso, a individualidade do ator se apresenta. Nesse contexto, o ator que "vive" o personagem acaba por "interpretar a si mesmo", o que, para Simmel, tem o significado de um realismo subjetivo: o conteúdo do personagem seria apenas um pretexto para o ator afirmar a sua individualidade. Desse modo, quando esse tipo de ator se "sai bem" ao desempenhar um personagem, quando ele "toca na profundidade do contexto", isso é resultado de "uma coincidência do acaso" entre a subjetividade do ator e o personagem.

Na perspectiva de Simmel, tal forma de representação “efetuada de modo temperamental, do impulso em si” ainda não é a forma artística de representação. Pois, “representar a si mesmo” é algo que todos os indivíduos fazem na vida cotidiana, sobretudo, na modernidade. Todos nós somos "atores" na vida, desempenhamos inúmeros papéis sociais, o que não nos torna atores no sentido artístico.

Ao que tudo indica, a questão que o "grande ator" apresenta para se pensar a idéia de ator moderno é também o seu limite para se afirmar como "ator artístico": o engrandecimento de sua 
personalidade. Por um lado, o "grande ator" se sobrepõe ao texto e, com isso, se autonomiza do autor; desse modo, contrapõe-se à idéia do ator como uma "ostra racional”, cuja tarefa seria apenas compor mecanicamente o personagem de acordo com os princípios da obra literária ou da realidade. Por outro lado, o "grande ator” também sobrepõe a sua personalidade ao personagem e, assim, "nega" a sua arte: passar-se por outro.

De qualquer maneira, a contribuição do "grande ator" está dada: ele alerta para uma subjetividade do ator, que é individual, mas que só se traduzirá em uma subjetividade propriamente artística no tipo de ator que nasce a partir da "complexificação" da vida moderna que se desenvolve nas metrópoles e vai ganhar expressão, especificamente, na concepção de Stanislavski.

\section{O ator-psicológico-criador a partir de Simmel e de Stanislavski}

Para Simmel (1998), os "aspectos metafísicos" dos individualismos quantitativo e qualitativo aparecem como "projeções econômicas", como dois grandes princípios que se reúnem na economia do século XIX. A liberdade individual fundamentada na igualdade natural entre os homens se projeta no princípio da livre concorrência. A ênfase na originalidade, ou melhor, a radicalização da "individualidade até a singularidade do ser e do desempenho" se projeta no princípio da divisão do trabalho. A união desses dois princípios se manifesta na vida metropolitana, dando-lhe duas características marcantes: por um lado, o intelectualismo e a calculabilidade; por outro, a indiferença.

O intelectualismo e a calculabilidade são as faculdades enfatizadas pelo próprio modo de vida sob o signo do dinheiro, ou seja, pela vida metropolitana: a necessidade de "medidas objetivas" 
que faz com que cada um calcule seu tempo, suas ações e seus resultados no seu dia-a-dia. À medida que o dinheiro se torna um fim em si mesmo, em busca dele, o indivíduo nivela, quantifica ou, ainda, monetiza todos os valores não monetários.

Para Simmel, a calculabilidade e o efeito nivelador do dinheiro produzem a indiferença, uma vez que comprometem a capacidade de sentimento e de vontade do indivíduo. Melhor dizendo, são tantos e tão diversos os "estímulos" das grandes cidades - com a sua “multidão' e os vários "símbolos” criados para organizar essa vida em multidão - que iso resultaria em um "excesso" para os "nervos" do indivíduo. Desse modo, para se adaptar a esse ritmo de vida, o indivíduo acaba desenvolvendo, nas palavras de Velho, "uma espécie de capa protetora, uma indiferença, como defesa da ameaça de fragmentação" (Velho, 1999a, p. 18).

Concebida nesses termos, a indiferença corresponde ao movimento do indivíduo qualitativo de "distanciar-se” da realidade exterior e refugiar-se dentro de si mesmo, reservar-se. Portanto, nessa atitude de reserva encontra-se a possibilidade do desenvolvimento da subjetividade, ou seja, de o indivíduo se afirmar como único e distinto. Trata-se de uma forma específica de "sociação" que se desenvolve na vida metropolitana, na qual experimentamos a liberdade de seguir "as leis de nossa própria natureza” (Simmel, 1976, p. 21). É a isso que Simmel chama de "liberdade individual possível" que, conforme advertem Souza e Berthold (1998), não é sinônimo de ausência de vínculos; ao contrário, tal liberdade é derivada da "multiplicidade de vínculos" que a vida metropolitana, sob o signo do dinheiro, oferece ao indivíduo.

No palco da metrópole, o sujeito se insere em um amplo contexto de "constrangimentos e obrigações", se vincula aos outros, mas, ao contrário do que ocorria na sociedade tradicional, ele, agora, tem a liberdade de se movimentar pelos vários grupos sociais. Atentar 
para essa liberdade de movimento, que também é a possibilidade de escolha individual, é considerar a sociedade não somente pelos seus fatores estruturais, mas também, como observam Souza e Berthold (1998), pelos aspectos mais cotidianos da vida dos indivíduos, na qual cada um age, cria o mundo a sua volta e a si mesmo, mas sempre em relação com os outros.

Por isso mesmo, a concepção de sociedade de Simmel é definida como uma realidade inter-humana: as "múltiplas interações de uns-com-os-outros, contra-os-outros e pelos-outros" (Moraes Filho, 1983, p. 21). A sociedade, portanto, é algo que está se constituindo, que está em processo. Assim, a análise simmeliana trabalha com a ambigüidade da experiência social moderna, ou seja, consegue perceber que a vida na sociedade moderna não implica só nivelamento ou integração; ela também implica distinção, o que sugere conflito, tensão, pois, por um lado, o indivíduo tem a necessidade de se integrar, de pertencer à sociedade (aos seus vários grupos constitutivos), de se "nivelar" aos outros. Por outro lado, há a necessidade de se distinguir da "massa homogênea”, de se singularizar, de afirmar a sua individualidade perante os outros, de ser único e distinto. Nesse duplo movimento do indivíduo dentro da vida moderna, Simmel chega a sua concepção de indivíduo moderno como tendo um caráter duplo: ele é um elemento no todo e, ao mesmo tempo, um todo em si mesmo.

Da mesma forma que concebe o indivíduo moderno a partir das duas dimensões da vida social expressas no individualismo quantitativo e no qualitativo, a meu ver, Simmel também desenvolve a sua noção de "ator artístico" a partir do que estou chamando de “ator-racional-realizador” e "grande ator”.

Simmel segue a perspectiva de Schiller, segundo a qual é próprio ao artista em geral "se eleva(r) acima da realidade" e "permanece(r) dentro do sensitivo". Assim, enquanto a "realidade é algo metafísico" - uma "teia" entrecruzada por várias dimensões 
da existência real, na qual cada fio ou fragmento não é uma unidade fechada em si, portanto, não pode ser decomposta em impressões sensoriais, a arte se situa no sensitivo - sua essência está em "projetar nesse fragmento de realidade o conteúdo da existência como um todo" (Simmel, 1994, p. 154); em outras palavras, configurar o conteúdo da existência em uma unidade. Portanto, de acordo com Simmel, o artista sempre nos conduz para o sensitivo, não para a realidade. Do mesmo modo, a arte dramática não é uma ponte que conduz à finalidade da realidade. A arte dramática, a arte do ator, tem raiz e finalidade próprias que são o desempenho artístico, dramático, em si. Assim como existe uma atitude pictórica e literária na vida real, há também uma atitude dramática, mas essas atitudes, por si mesmas, não são um desempenho artístico: elas dizem respeito às funções que constituem a nossa vida real, ou seja, inserem-se na prática da vida real, onde, por exemplo, todos nós, inevitavelmente, representamos certos papéis que podem se adequar à nossa individualidade, mas que também são algo diferente dessa individualidade.

Portanto, a representação de um papel na vida real é a raiz da arte dramática, a sua forma preliminar. Todavia, segundo Simmel, a representação de um papel, de um personagem, só se torna arte quando se abstrai da realidade, quando se eleva do interior da vida, da qual se alimenta, para tomar uma forma artística própria. Ou seja, quando se coloca no outro plano da vida, que se encontra além da realidade. Desse modo, a arte do ator se autonomiza, mostra seu caráter independente.

Para esse autor, a forma de representação de determinado personagem não é deduzida do objeto em si (do próprio personagem objetivado no texto pelo autor), nem do sujeito em si (da personalidade do ator por si só), mas, sim, da relação entre sujeito e objeto: da relação ideal entre o “eu real” e a “obra literária real”, logo, da maneira pela qual determinada individualidade dramática (o ator artístico) deve ser moldada de acordo com determinado personagem tirado da literatura. 
Nesse sentido, de acordo com Simmel, o ator não se submete à realidade - nem à realidade exterior, nem à realidade subjetiva. O ator se eleva sobre a "realidade do domínio do drama”. Isto é, o personagem contido no drama, na obra poética, não é um ser humano no sentido material, mas, sim, "um complexo do tangível literário de um ser humano" (Simmel, 1967, p. 75). Portanto, o texto se encontra em um plano mental e unidimensional, em que o escritor traça o destino e a "alma” do personagem. Entretanto, o autor não pode dar conta, em sua obra, das "premissas inequívocas”, da entonação e velocidade com que se fala, dos gestos, da "atmosfera" visual da figura ou de sua vivacidade ("o calor da vida"). É o ator quem transfere o texto desse plano unidimensional para o plano tridimensional da sensibilidade plena.

A meu ver, a idéia de ator artístico de Simmel pode ser relacionada à idéia de ator contida no método que Stanislavski desenvolveu ao longo de sua trajetória como ator e diretor - o que significa dizer entre o ano de 1877, quando estreou, aos quatorze anos, como ator, e o ano de 1939, quando faleceu.

Partindo de certa insatisfação com a artificialidade do representar simbolizada pela figura do grande ator - artificialidade esta que, como vimos, traduz uma "falsa subjetividade" -, Stanislavski busca formas teatrais e, portanto, de representação que se aproximem do "movimento da vida". Inicialmente, ele percorre os caminhos naturalistas que se voltam para a tentativa de transpor a "realidade exterior" - da pura realidade ou da pura literatura - para o palco. Mas, como sempre estava atento para a forma artística, talvez tenha percebido, em certa medida, a "falsa objetividade" dessas iniciativas. Assim, à frente do "Teatro de Arte de Moscou", que formou com Vladimir Nemírovitch-Dântchenko (crítico, dramaturgo, diretor e professor da escola de atores da Filarmônica de Moscou), Stanislavski desenvolveu um tipo de teatro e uma forma de representação que ele próprio denominou de um 
“naturalismo espiritual”, em contraste com a "materialidade” que caracterizava, de maneira geral, as encenações naturalistas da época - mais preocupadas, por exemplo, com o "realismo" dos cenários e figurinos.

Como chama a atenção Carvalho (1985), até o final do século XIX, um ou outro ator se mostrou interessado em sublinhar, na publicação de suas biografias, "esta ou aquela característica sobre as relações ator-texto, ator-espetáculo, ator-público", mas foi Stanislavski que sistematizou o conjunto dessas relações denotando o aspecto psicológico do trabalho do ator. Para Carvalho, essa preocupação de Stanislavski se associa ao impacto causado pelas considerações de Freud na vida social e teatral do período, em que "o diretor, o ator, o público querem descobrir o núcleo de sentimento que vive em cada personagem, e no fundo da obra dramática” (Carvalho, 1985, p. 105).

É nesse sentido que o naturalismo "espiritual" de Stanislavski é também denominado de "psicológico". Por isso mesmo, estou chamando o novo tipo de ator, que surge, principalmente, a partir de suas contribuições, de ator-psicológico-criador. Essas contribuições se difundiram pelo mundo por meio de publicações de sua obra teórica, mas tal teoria é resultado de uma prática que se fundamenta na busca por uma forma de teatro e de representação que se revelasse inovadora e artística, algo que marca a trajetória de Stanislavski.

O método de Stanislavski busca conciliar duas dimensões do trabalho do ator. A primeira compreende ao "trabalho interior" do ator, ou seja, é como se Stanislavski deslocasse o "engrandecimento da personalidade" do ator para a sua vida interior, sua subjetividade “real”. É a partir de sua vivência que o ator se torna capaz de desenvolver uma interpretação, uma leitura subjetiva sobre determinado objeto - o personagem elaborado pelo dramaturgo e objetivado no texto. Esse é um dos momentos cruciais para que um determinado ator crie uma imagem artística, um personagem único 
que é fruto de sua interpretação. A segunda dimensão diz respeito à "construção exterior do personagem": o seu modo de andar, falar, gesticular, criado a partir da leitura subjetiva do ator e equilibrado com os diversos elementos cênicos - figurinos, maquiagem, cenários, luz, som, etc. - que possibilitam ao ator representar no palco de maneira natural, no sentido do "como se fosse" aquela alma exposta no palco.

Com efeito, esses dois momentos não podem ser pensados como desenvolvidos de forma isolada, pois o princípio que revolucionou a prática teatral do final do século XIX, cujo mérito é do naturalismo, de forma geral, é o da compreensão do espetáculo como composto de diversos elementos que recebem uma forma harmônica, um conjunto, pelas mãos do encenador ou diretor. Portanto, o trabalho do ator se desenvolve em uma "teia" de relações: com o próprio personagem a ser interpretado, o que requer uma compreensão da peça como um todo; com os demais personagens que se relacionam com o seu e, por conseguinte, com os outros atores com quem contracena; com os outros elementos que também estarão "representando algo" no palco - os objetos, a luz, o som, etc., e, sobretudo, com o diretor.

É nesse sentido que Guinsburg (2001, p. 42) se refere ao princípio do "ensemble artístico, a equipe que materializa a peça como uma produção conjunta”. Como adverte ele, não se trata de criação coletiva, mas, sim, de "trabalho em equipe", no qual todos os membros da realização cênica são conjugados e estruturados, de maneira adequada, pelo diretor, que não dá margem para "o simples capricho da improvisação”. Esse é o princípio das novas leis cênicas que Stanislavski, mais do que qualquer outro, estabeleceu especialmente para o ator.

Aqui se pode pensar, nos termos de Simmel, em uma “liberdade individual-artística possível”. O ator não está livre de todo e qualquer "constrangimento”, ou seja, não está livre de um 
contexto de obrigações. Ao contrário, a sua liberdade advém da "multiplicidade de vínculos"; cada elemento ou recurso cênico pode contribuir para ele ampliar o seu "campo de possibilidades" na criação do seu personagem. Da mesma forma, a liberdade do ator advém, ainda, da sua própria vivência, da subjetividade artística que foi desenvolvendo ao longo de sua trajetória, da sua formação, que amplia a sua capacidade de compreensão e interpretação dos símbolos contidos no texto.

O método de Stanislavski propõe uma forma de representação que se torna predominante ao longo do século XX, servindo como referência para os atores ainda nos dias de hoje. A meu ver, essa forma de representação pressupõe a concepção simmeliana de indivíduo moderno que apresenta o duplo caráter de ser, ao mesmo tempo, "um todo em si mesmo" e "um elemento no todo", uma vez que aponta para a proximidade e a distância que caracterizam o modo específico como os indivíduos interagem na experiência ambígua da vida moderna.

Dessa maneira, com relação ao personagem, o ator se aproxima e se distancia no seguinte sentido: com sua "personalidade artística”, ou seja, como "um todo em si mesmo", o ator se aproxima do personagem contido no texto, mergulhando em sua "alma" e lendo-a de acordo com a sua vivência; a partir dessa leitura subjetiva, o ator cria uma "imagem" ou figura cênica única, distanciada dele mesmo, embora tenha algo de si. Com relação aos outros atores e ao público, o ator também se distancia e se aproxima. A própria criação de uma "imagem" ou figura cênica única já significa um distanciamento que demarca a individualidade do personagem e da capacidade de criação artística do ator com relação aos demais atores no palco, destacando-se ao mesmo tempo aos olhos do público. Porém, ao mesmo tempo, é preciso que a “imagem” única que criou esteja sob uma determinada forma que seja reconhecível aos outros, portanto, deve ter algo que seja comum a todos e que permita a integração desse ator no todo: tanto "o todo do palco", contracenando com os 
elementos em cena que formam um conjunto, a harmonia, que é uma das principais características do teatro moderno, como "o todo da realidade”, a comunicação com o público.

Simmel e Stanislavski se encontram na valorização da relação entre a subjetividade do ator e a objetividade do personagem contida no texto. Ambos concebem o ator como criador, afirmando a dimensão artística do ator, que, em suas concepções, não se perde, ao contrário, se realiza como arte autônoma. Para Simmel (1967, 1992), a atuação do ator parte de dentro de si para fora: é a partir da relação de sua subjetividade artística com a imagem objetiva que o escritor estabeleceu no texto que o ator cria uma figura, o conteúdo que o ator oferece no palco, e seu desempenho é marcado por uma contradição interna: no palco, ele age com "uma espontaneidade irrompendo do fundo do ser" e apresenta "uma vida imediata” (Simmel, 1992, p. 424). Essa contradição parece significar que, embora o ator saiba o que acontecerá com o personagem na seqüência da cena, o próprio personagem que ele representa não sabe, logo, o agir espontâneo do ator no palco busca dar a dimensão de uma vida que se desenrola, que pulsa diante o espectador. Stanislavski parece dizer o mesmo com seu "naturalismo espiritual": é a partir da objetividade do texto que o ator começa a interpretar o personagem e a criar uma imagem artística que representará no palco. Ou seja, é a partir do estudo do contexto da peça e do contex to em que o dramaturgo escreveu o texto que o ator compreende e percebe as particularidades do personagem, recorrendo à sua "memória emotiva" para lhe "emprestar" as emoções, os movimentos naturais que propiciam a esse "não-ser" parecer ser no palco.

No palco, não estão nem o ator, nem o personagem tal como se encontra escrito no texto. Ali, o que vemos é uma imagem criada por um ator. Se outro ator interpretar e representar o mesmo personagem, a imagem será diferente. Daí a possibilidade de se falar de tantos Hamlets quantos forem os atores a representarem o personagem de Shakespeare. 
O exemplo que Simmel utiliza é bastante esclarecedor dessa idéia de ator. Diferentemente do tartufo da vida real - o vigarista e hipócrita - que quer ser julgado como sendo realmente um asceta devoto, o ator que representa o Tartufo de Molière não quer provocar uma impressão da realidade, mas, sim, fazer ressurgir a imagem sensitiva daquilo que está no texto do autor. E, uma vez que o único ser real que está no palco é o ator, ninguém no palco "é realmente devoto ou hipócrita”, já que o ator não é nenhum dos dois. Portanto, conclui Simmel (1967, p. 76), "o ser não tem o que fazer no palco". O palco é o lugar do não-ser, do sensitivo, não da realidade.

Como já indiquei, essa compreensão sobre a arte do ator parece ser a que predomina nos dias de hoje. Por certo, isso não significa dizer que os outros tipos ideais de ator assinalados aqui desapareceram dos palcos contemporâneos. Muitas vezes, eles podem ser identificados em uma mesma peça, por meio de dois atores com formações distintas que contracenam, ou podem ser observados como entrelaçados na trajetória de um mesmo ator, seja em decorrência do momento particular de sua formação, seja como uma "exigência" do personagem a ser representado ${ }^{8}$. De todo modo, para além da atuação no palco, o que prevalece, pelo menos no discurso dos atores profissionais da atualidade, deixa transparecer a inquietação artística entre o ser e o não-ser.

\section{Agradecimentos}

Agradeço os comentários preciosos de Glaucia Villas Bôas, Maria Claudia Coelho e Valter Sinder, assim como dos participantes do II Encontro Temático: Sociologia do Teatro da Pós-Graduação em Ciências Sociais (Instituto de Filosofia e Ciências Humanas/ Universidade Estadual do Rio de Janeiro - IFCH/UERJ, junho de 2006). 


\section{Notas}

1 Quando falo em discurso atual dos atores profissionais, utilizo como fonte tanto entrevistas dos que se dedicam a essa profissão, recolhidas ao longo da última década dos meios de comunicação - jornais, revistas, programas de televisão -, como também, e mais especificamente, os depoimentos de atores profissionais concedidos a mim por ocasião da realização de minha tese de doutorado, defendida em junho de 2005 pelo Programa de Pós-Graduação em Ciências Sociais da Universidade do Estado do Rio de Janeiro (PPCIS/UERJ.

2 Vale lembrar que, para Weber, a construção de tipos ideais abstratos é um meio de conhecimento da realidade; trata-se, nas palavras do autor, "de um quadro do pensamento, e não da realidade histórica, e muito menos da realidade 'autêntica', e não serve de esquema no qual se pudesse incluir a realidade à maneira de exemplar. Tem antes o significado de um conceito limite puramente ideal, em relação ao qual se mede a realidade a fim de esclarecer o conteúdo empírico de alguns dos seus elementos importantes, e com o qual esta é comparada. Tais conceitos são imagens sobre as quais construímos relações, pela utilização da categoria da possibilidade objectiva, que a nossa imaginação, formada e orientada segundo a realidade, julga adequadas" (Weber, 1974, p. 81).

3 Simmel pensa o mundo medieval, especialmente a aldeia medieval, como um "círculo relativamente pequeno firmemente fechado contra círculos vizinhos, estranhos ou sob qualquer forma antagônicos" e "cerradamente coerente", que, para se autopreservar, "só permite a seus membros individuais um campo estreito para o desenvolvimento de qualidades próprias e movimentos livres, responsáveis" (Simmel, 1976, p. 18). Essa estreiteza de possibilidades inviabilizaria a liberdade individual e, por conseguinte, o próprio desenvolvimento da subjetividade; portanto, o homem se pensaria como atrelado ao seu grupo.

4 Segundo Norbert Elias, o caráter específico da racionalidade de corte “deriva, em primeiro lugar, do planejamento calculado da estratégia de comportamento em relação a possíveis perdas e ganhos de status e prestígio sob a pressão de uma competição contínua pelo poder" 
(Elias, 2001, p. 110). Vale ressaltar que poder, aqui, não se confunde com poder econômico, uma vez que o "capital" era visto apenas como um meio para se alcançar um objetivo que, nas palavras de Elias, era "conservar uma 'realidade' social, no centro da qual estava o anseio de se distinguir da massa dos homens" (Elias, 2001, p. 113).

5 Como observa Berthold, a peça $O$ pai de família, de Diderot, foi o "grande modelo" do drama burguês, do novo drama de classe média, que, na avaliação do autor e crítico alemão Lessing, não era "nem francês nem alemão, nem de qualquer outra nacionalidade, mas simplesmente humano" (apud Berthold, 2001, p. 381).

6 De acordo com Mannheim (1963, p. 116), o pensamento progressista se caracteriza pela "consciência do possível". Isso significa dizer que os progressistas experimentam o presente como "o começo do futuro", pensam-no em termos abstratos e de conjunto. Nesse sentido, o seu reformismo ataca "o sistema", ou seja, "tende a suprimir um fato indesejável reformando todo o mundo circundante que torna possível sua existência".

7 A peça Cromwell, de Victor Hugo, foi publicada em 1827, entretanto, nunca fora encenada. Em seu prefácio, Hugo defende, conforme salienta Braga, "a utilização do 'grotesco e do sublime', não só no mesmo texto, como também no mesmo personagem” (Braga, 1994, p. 153).

8 Seria interessante observar a coexistência desses quatro tipos ideais de atores em um mesmo contexto ou, ainda, o entrelaçamento deles em uma mesma trajetória profissional. Penso aqui, especificamente, em um exercício que o ator Paulo Autran costumava fazer em palestras ou em certos eventos dos quais participava, e que certa vez presenciei. O ator apresentava o "Poema Enjoadinho", de Vinícius de Moraes, de três maneiras: uma primeira, que designava como uma "leitura em branco", mais fria, do próprio texto; uma segunda, que consistia em uma leitura histriônica e exagerada; e uma terceira, na qual, segundo ele, dramatizava o poema. Cada uma dessas leituras permite, em certa medida, apontar para um tipo ideal de ator: a primeira para o "atorracional-realizador"; a segunda para o "grande ator" e a terceira para o "ator-psicológico-criador”. Essa observação que faço aqui é apenas uma indicação do que será objeto de um futuro artigo. 
Between being and not being: the building process of the professional actor idea in the light of Georg Simmel

\begin{abstract}
In this article, I analyze the building process of the professional actor idea from its origin to the predominant speech of those who currently dedicate themselves to this activity. Based on the specialized literature on acting and in the light of Georg Simmel's reflections, I will present four ideal types of actor to demonstrate the changes in the notion of the actor and in its corresponding acting patterns in order to keep up with the validation of the individual along the modern period. The four ideal actor types are: the "declaimer-illustrator-actor", the "rational-producer-actor", the "great actor" and the "psychological-creative-actor". In the latter type I identify Stanislavski's idea of actor - which still marks the current speech of the professional actors to a great extent - and I associate it with Simmel's conception of modern individual that would be characterized by its ambiguity.
\end{abstract}

Key words: professional actor; individual; modernity; Georg Simmel.

\title{
Referências
}

BERTHOLD, Margot. História mundial do teatro. São Paulo: Perspectiva, 2001.

BRAGA, Claudia. O teatro romântico. In: NUÑEZ, C. F. P. et al. (Org.). O teatro através da história. Rio de Janeiro: Centro Cultural Banco do Brasil: Entourage Produções Artísticas, 1994.

CARVALHO, Angela Materno de. A commedia dell'arte. In: NUÑEZ, C. F. P. et al. (Org.). O teatro através da história. Rio de Janeiro: Centro Cultural Banco do Brasil: Entourage Produções Artísticas, 1994.

CARVALHO, Enio José Coimbra de. A formação do ator na história e na atualidade. 1985. Tese (Doutorado em Artes) - Escola de Comunicação e Artes (ECA), Universidade de São Paulo (USP), São Paulo. 
DIDEROT, Denis. Paradoxo sobre o ator. Lisboa: Hiena, 1993.

DUVIGNAUD, Jean. Sociologia do comediante. Rio de Janeiro: Zahar, 1972.

ELIAS, Norbert. A sociedade de corte. Rio de Janeiro: Zahar, 2001. . Ensaio sobre o desporto e a violência. In: ; DUNNING, E. A busca da excitação. Lisboa: Difel, 1997. . Mozart, sociologia de um gênio. Rio de Janeiro: Zahar, 1995. O processo civilizador. Rio de Janeiro: Zahar, 1994. v. 1 e 2.

GUINSBURG, J. (2001), Stanislavski e o teatro de arte de Moscou. São Paulo: Perspectiva, 2001. (Coleção Debates, 192.)

MACHADO, Rosi Marques. (2005), Através da "máscara": uma abordagem sociológica do discurso do ator sobre sua identidade e formação profissionais. 2005. Tese (Doutorado em Ciências Sociais) - Programa de Pós-Graduação em Ciências Sociais (PPCIS), Universidade do Estado do Rio de Janeiro (UERJ), Rio de Janeiro.

MANNHEIM, Karl. El pensamiento conservador. In: . Ensayos sobre Sociología y Psicología Social. México: Fondo de Cultura Económica, 1963.

MORAES FILHO, Evaristo. (1983), Georg Simmel: sociologia. São Paulo: Ática, 1983. (Coleção Grandes Cientistas Sociais, 34.)

ORTIZ, Renato. Cultura e modernidade. São Paulo: Brasiliense, 1991.

PRADO, Décio de Almeida. João Caetano: o ator, o empresário, o repertório. São Paulo: Perspectiva, 1972.

ROUBINE, Jean-Jacques. A arte do ator. Rio de Janeiro: Zahar, 1987.

. Introdução às grandes teorias do teatro. Rio de Janeiro: Zahar, 2003.

SIMMEL, Georg. A metrópole e a vida mental. In: VELHO, O. G. (Org.). O fenômeno urbano. Rio de Janeiro: Zahar, 1976. 
SIMMEL, Georg. Der Shauspieler die Wirklichkeit. In: Das Individuum und die Freiheit: essais. Frankfurt: M. S. Fischer, 1994.

. O indivíduo e a liberdade. In: SOUZA, Jessé; ÖELZE, Berthold (Org.). Simmel e a modernidade. Brasília, UnB, 1998.

. Zur Philosophie des Shauspielers. In:Aufsätze und Abhandlungen 1901-1908. Gesamtausgabe v. 8/II. Frankfurt: M. Suhrkamp, 1992.

Zur Philosophie des Shauspielers. In: Fragmente und Aufsätze: Aus dem Nachlass und Veröffentlichungen der letzten Jahre. Hildesheim: G. Olms, 1967.

SOUZA, Jessé; ÖELZE, Berthold (Org.). Simmel e a modernidade. Brasília: UnB, 1998.

VELHO, Gilberto. Individualismo e cultura: notas para uma antropologia da sociedade contemporânea. Rio de Janeiro: Zahar, 1999b.

Projeto e metamorfose: antropologia das sociedades complexas. Rio de Janeiro: Zahar, 1999a.

WAIZBORT, Leopoldo. As aventuras de Georg Simmel. São Paulo: Ed. 34, 2000.

Elias e Simmel. In: Dossiê Norbert Elias. São Paulo: Edusp, 1999.

WEBER, Max. Sobre a teoria das ciências sociais. Lisboa: Presença, 1974.

ZOLA, Émile. O naturalismo no teatro. In: $O$ romance experimental e o naturalismo no teatro. São Paulo: Perspectiva, 1982. 